\title{
INSTITUTIONAL ANALYSIS OF INTERNATIONAL PRACTICES OF WATER REUSE
}

\begin{abstract}
Institutional analysis involves taking into account the impact of institutions, both formal and informal, on the processes occurring in the economic system - in our case, the reuse of treated wastewater in the urban economy. Among the formal institutions of interest to us there are legislative acts and rules for regulating the water management complex, which are designed to ensure the effective provision of water to both organizations and enterprises at the municipal level, as well as the population, occupy a special place. The article gives a comparative analysis of relay-based regulatory institutions in the field of water supply in many countries, especially of modern Europe. Relevance is determined by the ability of institutions to ensure the sustainable development of water resources and prevent or mitigate the water crisis. It is additionally shown that the international, with emphasis on Europe, practices of reusing treated wastewater are an important element for solving environmental problems, compensating the negative impact of global climate change on urban ecosystems. Some features of regulation of water reuse as one of the possible alternative water sources in regions where they are limited are also discussed.

Keywords: formal and informal institutions, water reuse, sustainable development, urban management, international practices in the use and regulation of water resources.

JEL Classification: L31, O52, Q25, R58.
\end{abstract}

\section{Principles of Forming Institutions For Providing WATER ReuSe}

Forming institutions, especially for water resources problem solution, is a task of great importance which must attract attention of state or municipal bodies and should be based on the certain principles designed to ensure the effective provision of water to both organizations and enterprises, as well as the population. As to treated wastewater reuse the main principle formulated by UN Economic and Social Council in 1958 is as follows: the water of high quality shall not, unless it has in abundance, to be used for the purposes that allow use of water of lower quality.

The idea of this principle's emergence is clear enough: over the past 100 years the consumption of fresh water in the world has grown in 2 times - this growth has overtaken population growth. Many scholars believe that increased consumption of fresh water will continue to occur mainly due to: population growth; changes in the diet of the population and the increase in water consumption per person (in the world today, one person consumes an average of 2 times more than in 1900); the development of tourism (e.g., tourists in Grenada (Spain) use on average 7 times more water than locals; in Israel, water use by hotels along the river Jordan, believed to have caused the drying up of the Dead sea, where the water level since 1977 , fell by $16.4 \mathrm{~m}$ ); growth of water consumption from the industry (annually in the world for domestic, industrial and agricultural water supply consumes about 4,000 $\mathrm{km} 3 /$ year); growth of energy consumption. 
Experts suggest that if the existing approach to the use and reuse of water resources, by 2030 the gap between the need for fresh water and its range can reach 40\% (2030 WRG). Therefore, there is every reason to believe that water reuse in the near future will expand.

Wastewater must be seen not as a waste, from which you want to get rid of, but as a resource, which may be an important element in the sustainable management of water resources and become an important lever in solving freshwater shortages, mitigate the effects of climate change, have beneficial effects on the environment (Fontana, Fontana, 2016).

We will add also, that from the technical point of view the water reuse is a part of decision of the circular economy's problems, related to the water-supply and water control (Yerznkyan, Fontana, 2018). However technically feasible projects will not be realized from institutional, legal, economic and organizational barriers, bad perception of public, exhaustive quality and quantitative null data. These non-technical barriers are limitation for expansion of planning and adjusting of the water reuse, and they need in regulative documents.

\section{SOME DEFINITIONS CONCERNING THE WATER REUSE}

In this paper, speaking on the water reuse we have in mind above all its use in the city limits after cleaning of the households, and possibly, businesses and organizations. For clarity, we will give some definitions of this kind of water.

Water reuse is the use of water based on purified wastewater, especially in the urban area. Wastewater is cleaned before reaching a certain quality that is appropriate for its further use in limited applications, taking account of the legislation and the potential risks to human health and the environment.

Urban (municipal) wastewater is domestic waste water or the mixture of domestic waste water with industrial, located within the city limits and having common stock. Urban and industrial wastewater has different characteristics (e.g., on the content of organic matter, pathogens, heavy metals, etc.) that affect the way they clean for reuse.

Direct reuse refers to the supply of treated wastewater to the consumer using an appropriate infrastructure, in particular a dedicated pipeline. Indirect reuse refers to the collection of water from natural sources for subsequent use, where the discharge of (partially) treated effluents was previously carried out. Planned reuse refers to systems organized for the supply and use of treated wastewater that has been treated in accordance with its further use. Unplanned reuse means the out-of-control repeated use of effluents after their hit in natural reservoirs. For example, consumers «below down stream» use water from the river in that an up-cast comes true higher down stream (Yerznkyan, Fontana, 2019b, p. 17).

\section{WATER REUSE IN RUSSIA AND ABROAD}

In Soviet-period Russia, water treatment was made by the methods that included capital investments in sewage treatment plants and their subsequent exploitation, and also positive influence on chemical composition and agro-melioration properties of irrigable soils, productivity of rural economy cultures. The similar systems and practices were recommend- 
ed to wide introduction in practice of agricultures production, but however in future wide distribution of treated wastewater reuse did not get.

In contemporary Russia, in spite of the fact that in «Water strategy of Russian Federation on a period till 2020» is indicated, that the increase of rationality of water consumption is arrived at by the decline of losses of water at transporting, reduction of specific consumption of water in technological processes, on service-utility needs, and the last is arrived at by «expansion of the use of the circulating and repeatedly-successive water systems», wastewater is used mainly in industry or thrown down in natural reservoirs.

In practice, however, water is counted not as the main resource of life-support of population, but as the expense material. Water reuse of effluents is not examined in a number priority at the decision of ecological and socio-economic tasks, and also as an important element of steady development of water resources neither in Water strategy of Russian Federation on a period till 2020, nor in Strategy of ecological safety of Russian Federation on a period till 2025, nor in other legislative acts.

In abroad, there are more than thirty legislative acts concerning water reuse in whose development participate a lot of organizations, such as the UNO, OECD, World Bank, etc. From the point of the view of institutional analysis it is remarkablr that many of mentioned acts and documents do not have analogues in the Russian formal, i.e. legal, field. A situation is complicated by that «in the conditions of realization in regard to RF of politics of inhibition, the threat of access to foreign environmentally clean innovations, technologies, materials and equipment restriction is formed» (Strategy..., 2025, point 23).

According to the rules and norms accepted in RF, all effluents (before their up-cast in reservoirs) must be cleared to the level of maximum to the possible concentration and approximately safe levels of influence corresponding to the up-cast in the reservoirs and currents, intended for the economic-drinkable, cultural and welfare or fishing industry setting.

Afterwards, for providing of population by drinking-water and satisfaction of urban and rural economies' needs, water is perched from natural water sources, including reservoirs, where earlier an up-cast came true. Thus, for consumers «below down stream» we look after «unplanned indirect water reuse», that officially does not confess authorities, and the population is not informed of it (Yerznkyan, Fontana, 2019b, p. 18).

\section{FORMAL INSTITUTIONS IN EUROPEAN UNION}

There are a variety of formal institutions on whater reuse in European Union (EU), namely the directives of the European Parliament and of the Council. Here are the main of them (Yerznkyan, Fontana, 2019b, p. 20-21):

1. Directive 91/271/EEC of 21 May 1991 on the urban wastewater treatment. Official Journal. L 135/40, 30 May 1991.

2. Directive 91/676/EEC of 12 December 1991 on the protection of waters against pollution caused by nitrates from agricultural sources. Official Journal. L 375/1, 31 December 1991. 
3. Directive 98/83/EC of 12 December 2006 on the quality of water intended for human consumption. Official Journal. L 330/32, 5 December 1998.

4. Directive 2000/60/EC of 23 October 2000 establishing a framework for community action in the field of water policy. Official Journal. L 327, 22 December 2000.

5. Directive 2006/7/EC of 15 February 2006 concerning the management of bathing water quality and repealing Directive 76/160/EEC. Official Journal. L 64/37, 4 March 2006.

6. Directive 2006/118/EC of 12 December 2006 on the protection of groundwater against pollution and deterioration. Official Journal. L 372/19, 27 December 2006.

7. Directive 92/43/EEC of 21 May 1992 on the conservation of natural habitats and the wild fauna and flora. Official Journal. L 206, 22 July 1992.

8. Directive 2009/147/EC of 30 November 2009 on the conservation of wild birds. Official Journal. L 20/7, 26 January 2010.

9. Directive 2006/44/EC of 6 September 2006 on the quality of fresh waters needing protection or improvement in order to support fish life. Official Journal. L 264/20, 25 September 2006.

10. Directive 2006/113/EC of 12 December 2006 on the quality required of shellfish waters. Official Journal. L 376/14, 27 December 2006.

It should be, however, mentioned thatr all these directives are used partially.

\section{COMPARATIVE INSTITUTIONAL ANALYSIS}

The results of the analysis are summarized in table.

Table

\section{European Water Reuse Regulative Institutions}

\begin{tabular}{l|l|l}
\hline Country & $\begin{array}{l}\text { Modern state of consumption of water, } \\
\text { including the water reuse }\end{array}$ & $\begin{array}{l}\text { Rules of application and stimulation of } \\
\text { financing of the water reuse }\end{array}$ \\
\hline Austria & $\begin{array}{l}\text { The deficit of water is observed in some east } \\
\text { and south districts. About 98\% of drinking- } \\
\text { water perches from subsoil waters and practi- } \\
\text { cally does not require cleaning }\end{array}$ & $\begin{array}{l}\text { water reuse regulation. A primary purpose } \\
\text { of water politics is the rational water reuse } \\
\text { which is recommended in the cases when } \\
\text { it results in economic and/or ecological } \\
\text { advantages. Thus, for the some industrial } \\
\text { sectors there are limitations of the use of } \\
\text { natural water and repeated its use is rec- } \\
\text { ommended }\end{array}$ \\
\hline
\end{tabular}




\begin{tabular}{|c|c|c|}
\hline Country & $\begin{array}{l}\text { Modern state of consumption of water, } \\
\text { including the water reuse }\end{array}$ & $\begin{array}{l}\text { Rules of application and stimulation of } \\
\text { financing of the water reuse }\end{array}$ \\
\hline Belgium & $\begin{array}{l}\text { High index of water stress. Cleaning is passed } \\
\text { by } 70 \% \text { of effluents for their subsequent RU } \\
(10 \text { back this number made } 38 \%) \text {. Hasty } \\
\text { growth of modern sewage treatment plants } \\
\text { improved the prospects of the repeated use. } \\
\text { Reduction of upcast of effluents in the natural } \\
\text { sources of water is other reason of RU of wa- } \\
\text { ter }\end{array}$ & $\begin{array}{l}\text { In } 2003 \text { Flemish regional Department on } \\
\text { water resources offered to Government on } \\
\text { the basis of Australian leading principles of } \\
\text { EPA to work out the criteria of RU of wa- } \\
\text { ter. Belgian Government would like to } \\
\text { shorten the volumes of fence of subsoil } \\
\text { waters and stimulate RU of water. Interest } \\
\text { in RU is growing in the country, especially } \\
\text { in water cooling systems at power plants, } \\
\text { food and textile enterprises, in agriculture } \\
\text { (although the share of treated wastewater is } \\
\text { still limited), in coastal areas during the } \\
\text { tourist season. Reducing discharges in eco- } \\
\text { logically sensitive areas is also the reason } \\
\text { for the development and implementation of } \\
\text { RU TWW projects }\end{array}$ \\
\hline Bulgaria & $\begin{array}{l}\text { In spite of the fact that Bulgaria is the second } \\
\text { country in EC with the most index of water } \\
\text { stress, no certain data, touching TWWRU, } \\
\text { does not exist }\end{array}$ & $\begin{array}{l}\text { Presently Government examines leading } \\
\text { principles on introduction of water reuse }\end{array}$ \\
\hline $\begin{array}{l}\text { Czech } \mathrm{Re}- \\
\text { public }\end{array}$ & $\begin{array}{l}\text { It is on the watershed of three seas, and the } \\
\text { most Czech currents перетекают in nearby } \\
\text { countries. Priority questions are quality of } \\
\text { water and level of contamination SR. Politics } \\
\text { of Government is sent to reduction of volume } \\
\text { of water intake in a public sector and in in- } \\
\text { dustry. However, any certain data about reali- } \\
\text { zation of projects TWWRU are not found out }\end{array}$ & $\begin{array}{l}\text { No provisions or guidelines have been } \\
\text { adopted }\end{array}$ \\
\hline$\overline{\text { Cyprus }}$ & $\begin{array}{l}\text { A shortage of water and worsening of the } \\
\text { state of water on beaches are the retentive } \\
\text { factors of development of tourism that is the } \\
\text { important type of economic activity. } \\
\text { TWWRU is an important contribution to the } \\
\text { decision of problem of deficit of water not } \\
\text { only in the field of tourism but also agricul- } \\
\text { ture, maintenances of green plantations, fields } \\
\text { for golf. TWW is an irreplaceable source and } \\
\text { it is necessary to expect the increase of vol- } \\
\text { umes of its use, that still will be in the future }\end{array}$ & $\begin{array}{l}\text { From } 1990 \text { to } 2005 \text { temporal standards op- } \\
\text { erated for TWWRU with mark criteria of } \\
\text { quality for irrigation. These standards more } \\
\text { hard, than Leading principles take into ac- } \\
\text { count the certain terms of Cyprus. With } \\
2005 \text { these standards went across from sta- } \\
\text { tus «temporal» to «permanent» (Decree of } \\
\text { N296/03.06.05) }\end{array}$ \\
\hline Denmark & $\begin{array}{l}\text { The index of water stress is appraised be- } \\
\text { tween } 15 \text { and } 20 \% \text {. A water-supply almost } \\
\text { fully depends on the state of subsoil waters. } \\
\text { Therefore management a primary value has } \\
\text { quality and amount of subsoil waters for a } \\
\text { steady water-supply and water consumption. } \\
\text { As well as in other Scandinavian countries, a } \\
\text { question about TWWRU is not examined se- } \\
\text { riously }\end{array}$ & $\begin{array}{l}\text { In 1990th Ministry of environment rendered } \\
\text { sponsorship to a few initiatives on introduc- } \\
\text { tion in the private sector (hoesholds) of } \\
\text { practices of utilization of «grey» water for } \\
\text { domestic aims. Some positions or leading } \\
\text { principles are not accepted }\end{array}$ \\
\hline Estonia & $\begin{array}{l}\text { The index of water stress makes about } 10 \% \text {. } \\
\text { Large attention is spared to cleaning of efflu- } \\
\text { ents before an upcast. Last years in a number } \\
\text { of cities modern new sewage treatment plants } \\
\text { are opened. Utilization of effluents is not } \\
\text { used, except for a limit amount on some in- } \\
\text { dustrial enterprises }\end{array}$ & $\begin{array}{l}\text { No provisions or guidelines have been } \\
\text { adopted }\end{array}$ \\
\hline
\end{tabular}




\begin{tabular}{|c|c|c|}
\hline Country & $\begin{array}{l}\text { Modern state of consumption of water, } \\
\text { including the water reuse }\end{array}$ & $\begin{array}{l}\text { Rules of application and stimulation of } \\
\text { financing of the water reuse }\end{array}$ \\
\hline$\overline{\text { Finland }}$ & $\begin{array}{l}\text { With water reserves of more than } 20,000 \mathrm{~m} 3 / \\
\text { year per capita, the country does not need to } \\
\text { consider the issues of TWWRU for irrigation }\end{array}$ & $\begin{array}{l}\text { No provisions or guidelines have been } \\
\text { adopted }\end{array}$ \\
\hline France & $\begin{array}{l}\text { From the beginning of 1990th French Gov- } \\
\text { ernment is concentrated on the question of } \\
\text { TWWRU in connection with development of } \\
\text { irrigable agriculture with the use of plenty of } \\
\text { fertilizers and water. Growing demand on } \\
\text { water in agriculture is accompanied by the } \\
\text { becoming more frequent cases of drought. } \\
\text { Running into such situation, authorities forced } \\
\text { to impose restriction on the use of water. } \\
\text { About } 15 \text { French departments are located in } \\
\text { zones with the Mediterranean climate that } \\
\text { befits for gardening and tourism. All of it, as } \\
\text { a rule, increases a requirement in water in the } \\
\text { conditions of limit nature WR. However prac- } \\
\text { tices of TWWRU will be realized mainly on } \\
\text { island part of France, mainly from the high } \\
\text { cost of tertiary treatment. Nevertheless, the } \\
\text { realized projects overcame territory more than } \\
3000 \text { ha, and have a wide enough spectrum of } \\
\text { application : gardening, including orchards, } \\
\text { grain-crops, plantations of trees }\end{array}$ & $\begin{array}{l}\text { In } 1991 \text { were published Recommendations } \\
\text { on a health care at TWWRU for watering of } \\
\text { agriculture and green plantations (Health } \\
\text { Guidelines for reuse, after treatment, of } \\
\text { waste water for crop and green spaces irri- } \\
\text { gation), that shows that projects waters RU } \\
\text { must get approval of health (that corre- } \\
\text { sponds to Leading principles of World } \\
\text { Health Organization) authorities. In Febru- } \\
\text { ary } 1996 \text { Association of specialists for a } \\
\text { water-supply and sewage system (Associa- } \\
\text { tion of Water Supply and Sewerage Practi- } \\
\text { tioners) published technical recommenda- } \\
\text { tions on cleaning of effluents. The most re- } \\
\text { newed rules touch TWWRU in agricukture. } \\
\text { Since 1996, Guidelines D94-463.3.1994 } \\
\text { DGS-SD1.D.9 }\end{array}$ \\
\hline Germany & $\begin{array}{l}\text { The accessible volumes of water arrive at } 182 \\
\text { billion m3/year, from that } 25,8 \% \text { is used only. } \\
\text { Thus, stimuli are absent for TWWRU. Never- } \\
\text { theless, direct RU is practiced in agriculture, } \\
\text { and on some territories (valleys of the river } \\
\text { Rhine) - for artificial addition to the under- } \\
\text { waters. During the last } 120 \text { there is practice of } \\
\text { mixing of the cleared (to the certain level) } \\
\text { flows with surfaces waters in Berlin }\end{array}$ & $\begin{array}{l}\text { Federal Law on Water (Federal Water Act) } \\
\text { from one side, provides the high level of } \\
\text { defence of WR, and with other, gives the } \\
\text { best possibilities for the repeated use of ef- } \\
\text { fluents, taking into account the guard of en- } \\
\text { vironment. In spite of absence of stimuli on } \\
\text { introduction of practices TWWRU, devel- } \\
\text { opments and researches proceed in this } \\
\text { sphere }\end{array}$ \\
\hline Greece & $\begin{array}{l}\text { Over the past } 50 \text { years, water demand has in- } \\
\text { creased dramatically. In spite of sufficient } \\
\text { amount of annual fallouts, the shortage of wa- } \\
\text { ter arises up from the seasonal and territorial } \\
\text { vibrations of fallouts, and also growing de- } \\
\text { mand on water in summer months, complica- } \\
\text { tions of transporting of water from mountain } \\
\text { locality. Therefore integration of purified- } \\
\text { sewages in the plans of management of WR is } \\
\text { an important for a country question. As more } \\
\text { than } 83 \% \text { of TWW is produced in water- } \\
\text { deficit regions, reuse uf such waters could } \\
\text { partially satisfy the demand for water in these } \\
\text { regions. More than } 88 \% \text { of the treated } \\
\text { wastewater is located at a distance of about } 5 \\
\text { km from the existing agricultural land. Thus, } \\
\text { the additional cost of irrigation with waste } \\
\text { water disposal will be low }\end{array}$ & $\begin{array}{l}\text { The directives of JMD 145116/11 (GGB' } \\
\text { 354/2011) and JMD 5673/400/1997 (GGB' } \\
\text { 192/1997) regulate ПИ of effluents, includ- } \\
\text { ing for drinkable aims (as a rule, by mixing } \\
\text { of the cleared water with subsoil waters) and } \\
\text { agriculture of irrigation }\end{array}$ \\
\hline
\end{tabular}




\begin{tabular}{|c|c|c|}
\hline Country & $\begin{array}{l}\text { Modern state of consumption of water, } \\
\text { including the water reuse }\end{array}$ & $\begin{array}{l}\text { Rules of application and stimulation of } \\
\text { financing of the water reuse }\end{array}$ \\
\hline Hungary & $\begin{array}{l}96 \% \text { of surface-water acts from nearby coun- } \\
\text { tries. In this connection, quality and amount } \\
\text { of water largely depend on politics of nearby } \\
\text { countries at a management WR. Nevertheless, } \\
\text { Hungarian industry and agriculture bring in } \\
\text { the contribution to contamination of water. } \\
\text { More than } 90 \% \text { of drinking-water acts from } \\
\text { subsoil waters, her defence is a strategic task } \\
\text { in Hungary }\end{array}$ & $\begin{array}{l}\text { There are numerous separate rules and } \\
\text { norms, touching water RU. Single legisla- } \\
\text { tive acts, touching the repeated use of water, } \\
\text { are absent. However Program on an envi- } \\
\text { ronment (Decision 96/2009 XII.9) and man- } \\
\text { agement Plan assist river pools to the steady } \\
\text { use of WR and water RU for defence and } \\
\text { maintenance of quality and amount of ac- } \\
\text { cessible water. These programs envisage } \\
\text { TWWRU on territories suffering from the } \\
\text { shortage of water }\end{array}$ \\
\hline Ireland & $\begin{array}{l}\text { About } 75 \% \text { of drinking-water acts from sur- } \\
\text { face-water, other - from mining holes. From a } \\
\text { mild and moist climate requirement in agri- } \\
\text { culture irrigation is practically absent. To pre- } \\
\text { sent tense no practices of TWWRU were } \\
\text { marked }\end{array}$ & $\begin{array}{l}\text { No provisions or guidelines have been } \\
\text { adopted }\end{array}$ \\
\hline Italy & $\begin{array}{l}\text { The Italian sewage treatment plants can pro- } \\
\text { duce to } 2.400 \mathrm{Mm} 3 / \text { year of useful water. Pres- } \\
\text { ently TWW is used mainly for irrigation of } \\
\text { agricultural lands. In Turin there are practices } \\
\text { of ПИ of water in industry }\end{array}$ & $\begin{array}{l}\text { The use of effluents in irrigation in Italy is } \\
\text { regulated with } 1977 \text { (Water Protection Act, } \\
\text { Annex 5, CITAI, 1977). This Law regulates } \\
\text { the process of cleaning of effluents and was } \\
\text { strict enough, but here he does not set some } \\
\text { standards on a possible level toxic or biosto- } \\
\text { ry substances in soil. Some regional gov- } \\
\text { ernment (for example, in Apulia and Sicily) } \\
\text { bodies, using the plenary powers (according } \\
\text { to Law on protecting of water from 1976), } \\
\text { worked out local regional standards on wa- } \\
\text { ter RU. In accordance with Decree of Minis- } \\
\text { try, N185/03 from 12.06.2003 (Ministry } \\
\text { Decree, D.M. no 185/03) and by Law- } \\
\text { decree of N152 (Law - Decreen. 152, 2006) } \\
\text { a vault was worked out governed in relation } \\
\text { to water RU for agriculture and undrinkable } \\
\text { municipal and industrial needs. The nega- } \\
\text { tive aspect of the Italian legislation is an } \\
\text { excessive abundance of parameters (more } \\
\text { than 50) that must be taken into account at } \\
\text { monitoring of the cleared flows with high- } \\
\text { frequency of realization of monitoring. Thus } \\
\text { Rules are not set distinctions as water for } \\
\text { watering of the different agriculture, not } \\
\text { paid attention to influence of different types } \\
\text { of irrigation (superficial irrigation tiny) for } \\
\text { the decline of sanitary risks }\end{array}$ \\
\hline
\end{tabular}




\begin{tabular}{|c|c|c|}
\hline Country & $\begin{array}{c}\text { Modern state of consumption of water, } \\
\text { including the water reuse }\end{array}$ & $\begin{array}{l}\text { Rules of application and stimulation of } \\
\text { financing of the water reuse }\end{array}$ \\
\hline$\overline{\text { Latvia }}$ & $\begin{array}{l}\text { Quality of fresh waters and their defence are } \\
\text { one of basic priorities of ecological politics of } \\
\text { Latvia. For providing of the rational use and } \\
\text { their long-term defence WR was certain as } \\
\text { important national property. At the same time } \\
\text { water RU is not a priority task }\end{array}$ & $\begin{array}{l}\text { In accordance with the decisions of Cabinet } \\
\text { of Ministers and Water legislation of EC, } \\
\text { the row of fundamental laws (with 2000) } \\
\text { was accepted for providing of steady devel- } \\
\text { opment of water ecosystem. As a result, } \\
\text { control system by SR was reorganized and } \\
\text { certain measures are pre-arranged on the } \\
\text { guard of environment for the catchment ba- } \\
\text { sins of the rivers. Management plans are } \\
\text { also worked out by river pools. All Latvia } \\
\text { marked as highly sensitive territory for that } \\
\text { the special requirements are used on clean- } \\
\text { ing of municipal sewer }\end{array}$ \\
\hline Lithuania & $\begin{array}{l}\text { TWWRU does not exist. Greater part of the } \\
\text { cleared flows is thrown down in superficial } \\
\text { reservoirs }\end{array}$ & $\begin{array}{l}\text { Some positions or leading principles are not } \\
\text { accepted }\end{array}$ \\
\hline Loxemburg & $\begin{array}{l}\text { Does not test problems with providing fresh } \\
\text { water population and economy of country on } \\
\text { the whole. TWWRU does not stand on an } \\
\text { order-paper. Nevertheless, in order that to } \\
\text { protect it to SR some positions were accepted } \\
\text { recommending TWWRU in industry, includ- } \\
\text { ing in the systems of cooling }\end{array}$ & $\begin{array}{l}\text { Some positions or leading principles are not } \\
\text { accepted }\end{array}$ \\
\hline Mallta & $\begin{array}{l}\text { It is on the sharp shortage of water. As agri- } \\
\text { culture is the basic source of acuests, } \\
\text { TWWRU for irrigation is practiced with } 1884 \\
\text { (to save fresh water for the domestic use). In } \\
1986 \text { possibility of TWWRU was considered } \\
\text { in industry. Realization of similar projects } \\
\text { depends in this case, mainly, from economic } \\
\text { terms, in particular, comparisons of general } \\
\text { charges on TWWRU with other sources of } \\
\text { water (for example, by a desaltation) }\end{array}$ & Leading principles are in development \\
\hline $\begin{array}{l}\text { The Nether- } \\
\text { lands }\end{array}$ & $\begin{array}{l}\text { Some regions on a south-west, east and north- } \\
\text { east of country are on the shortage of water } \\
\text { during droughts. TWWRU is possible at irri- } \\
\text { gation of agriculture under reaching certain } \\
\text { quality of water, and also in industry (for ex- } \\
\text { ample, in the systems of cooling). In rare cas- } \\
\text { es, such water is used to maintain the level of } \\
\text { the aquifer, as well as for fire fighting and } \\
\text { other urban purposes. } \\
\text { To date the general volume of cleaning and } \\
\text { TWWRU is small. In the nearest future ПИ } \\
\text { will be, probably, to increase, if it will be }\end{array}$ & $\begin{array}{l}\text { Introduction of taxes and limits on the fence } \\
\text { of water from aquiferous horizon (for re- } \\
\text { newal of primary water-table), TWWRU } \\
\text { becomes more attractive. In a number of } \\
\text { regions projects are realized renewals of } \\
\text { wetlands with the use of the cleared flows, } \\
\text { demonstrating ecological advantages of } \\
\text { such approach }\end{array}$ \\
\hline
\end{tabular}




\begin{tabular}{|c|c|c|}
\hline Country & $\begin{array}{c}\text { Modern state of consumption of water, } \\
\text { including the water reuse }\end{array}$ & $\begin{array}{l}\text { Rules of application and stimulation of } \\
\text { financing of the water reuse }\end{array}$ \\
\hline Poland & $\begin{array}{l}\text { Politics in area of water-supply and sewage } \\
\text { system is sent both to the decline of consump- } \\
\text { tion of SR and on the decline of influence of } \\
\text { effluents on an environment. First of all, the } \\
\text { decline of influence is arrived at due to reduc- } \\
\text { tion of amount of upcast of effluents, and also } \\
\text { moving away ecologically of hazardous sub- } \\
\text { stances from effluents, application of the re- } \\
\text { served chains and TWWRU }\end{array}$ & $\begin{array}{l}\text { Local authorities, under the Law on local } \\
\text { self-government (The Local Government } \\
\text { Act on March, } 8 \text { 1990) must provide utiliza- } \\
\text { tion and cleaning of communal effluents. A } \\
\text { law on Water obligates Ministry on the } \\
\text { guard of environment to present a report in } \\
\text { Council of Ministers on realization of the } \\
\text { national program on cleaning of municipal } \\
\text { effluents (National Program of Municipal } \\
\text { Waste water Treatment), that was accepted } \\
\text { by Council of Ministers in 16.12.2003. The } \\
\text { program provides for the phased equipment } \\
\text { of all municipalities with combined sewer } \\
\text { systems and modern treatment facilities }\end{array}$ \\
\hline Portugal & $\begin{array}{l}57.5 \% \text { of mainland part of country suffers } \\
\text { from the deficit of water. South areas espe- } \\
\text { cially suffer from periodic droughts. The vol- } \\
\text { ume of treated wastewater exceeds } 480 \mathrm{~mm} 3 / \\
\text { year, which satisfies about } 10 \% \text { of the water } \\
\text { demand during irrigation during the dry peri- } \\
\text { od. In Portugal purified-sewages are a valua- } \\
\text { ble resource in irrigation }\end{array}$ & $\begin{array}{l}\text { National legislation of DL 236/87, } 1987 \text {, } \\
\text { XVI and XVII (in relation to the standards } \\
\text { of quality of water for irrigational applica- } \\
\text { tions in agriculture) determines the possible } \\
\text { norms of maintenance of metals, to micro- } \\
\text { biology and salinity in water for her subse- } \\
\text { quent use. In } 2005 \text { the national standard of } \\
\text { RU of the cleared municipal effluents was } \\
\text { accepted for irrigation in rural and forest } \\
\text { economies, lawns (including придомовой } \\
\text { territory), in nurseries (NP4434)., which sets } \\
\text { water quality standards, appropriate treat- } \\
\text { ment regimens, criteria for choosing the } \\
\text { most appropriate type of irrigation and } \\
\text { equipment, monitoring programs. In 2007 } \\
\text { Leading principles of national regulator are } \\
\text { accepted on the water-supply (ERSAR, } \\
\text { former IRAR) of relatively effluents and } \\
\text { wastes (Rec.IRARnr 2/2007). This docu- } \\
\text { ment sets leading principles for a production } \\
\text { and distribution of purified-sewages for irri- } \\
\text { gation, control of quality, base for the calcu- } \\
\text { lation of price on water and, who must pay. } \\
\text { In 2010 Technical Guidance of national } \\
\text { regulator is accepted on a water-supply, } \\
\text { sewage system and wastes of services } \\
\text { (ERSAR Technical Guidenr 14 N14), that } \\
\text { regulates the use cleared municipal and in- } \\
\text { dustrial sewer }\end{array}$ \\
\hline Romania & $\begin{array}{l}\text { TWWRU is reality in a few Spanish regions } \\
\text { in } 4 \text { th application domains: irrigation of golf- } \\
\text { fields, irrigation of agriculture earth, addition } \\
\text { to subsoil waters and increase of flow of the } \\
\text { rivers }\end{array}$ & $\begin{array}{l}\text { TWWRU is regulated by the Royal decree } \\
1620 / 2007 \text { from } 07.12 .2007 \text { (Royal Decree } \\
1620 / 2007 \text { ), that sets the legal mode for } \\
\text { TWWRU }\end{array}$ \\
\hline Slovakia & $\begin{array}{l}\text { Purified-sewages repeatedly not used for lack } \\
\text { of the effective sewage systems and modern } \\
\text { secondary sewage treatment plants }\end{array}$ & $\begin{array}{l}\text { No provisions or guidelines have } \\
\text { been adopted }\end{array}$ \\
\hline
\end{tabular}




\begin{tabular}{|c|c|c|}
\hline Country & $\begin{array}{c}\text { Modern state of consumption of water, } \\
\text { including the water reuse }\end{array}$ & \begin{tabular}{|c|}
$\begin{array}{c}\text { Rules of application and stimulation of } \\
\text { financing of the water reuse }\end{array}$ \\
\end{tabular} \\
\hline Slovenia & $\begin{array}{l}\text { Cleaning and water RU is one of priorities for } \\
\text { maintenance of wetlands. However, these } \\
\text { practices are used only on territory of small } \\
\text { communities and consequently have a limit } \\
\text { application. It is expected that in the near fu- } \\
\text { ture these practices will be widely used in } \\
\text { tourist districts }\end{array}$ & $\begin{array}{l}\text { No provisions or guidelines have been } \\
\text { adopted }\end{array}$ \\
\hline Spain & $\begin{array}{l}\text { TWWRU is reality in a few Spanish regions } \\
\text { in 4th application domains: irrigation of golf- } \\
\text { fields, irrigation of agriculture earth, addition } \\
\text { to subsoil waters and increase of flow of the } \\
\text { rivers. Private water companies, in collabora- } \\
\text { tion with universities, are investing in re- } \\
\text { search and development on this topic. Future } \\
\text { TWWRU is promising }\end{array}$ & $\begin{array}{l}\text { TWWRU is regulated by the Royal decree } \\
1620 / 2007 \text { from } 07.12 .2007 \text { (Royal Decree } \\
1620 / 2007 \text { ), that sets the legal mode for } \\
\text { TWWRU. The primary purpose of RD con- } \\
\text { sists in maintenance of equilibrium between } \\
\text { a health and environment care, providing } \\
\text { water of high quality. A decree determines } \\
\text { TWWRU as additional appendix of WR } \\
\text { after realization of the corresponding clean- } \\
\text { ing and achievement of quality of water, } \\
\text { according to the set requirements. Govern- } \\
\text { ment, regional and local authorities, for } \\
\text { stimulation of the repeated use of water }\end{array}$ \\
\hline Sweden & $\begin{array}{l}\text { In spite of high availability of WR and low } \\
\text { level of abstraction renewable WR (in all } \\
2 \% \text { ), in south-east part of country there is in- } \\
\text { terest in the use of tertiary treat effluents for } \\
\text { irrigation. Principal reason of such interest is } \\
\text { maintenance natural to WR. There are more } \\
\text { than } 40 \text { practices of TWWRU to date. Puri- } \\
\text { fied-sewages are about } 9 \text { months defended in } \\
\text { enormous reservoirs, before used for irriga- } \\
\text { tion. On occasion effluents interfuse with sur- } \\
\text { face-water. The nutritives contained in efflu- } \\
\text { ents are processed and afterwards used on } \\
\text { agriculture lands, and farmers get cheap water } \\
\text { for irrigation. This practice is advantageous } \\
\text { for authorities and water complex (as such } \\
\text { water is for sale and not spent money on } \\
\text { building and exploitation of expensive sew- } \\
\text { age treatment plants), and for farmers (be- } \\
\text { cause they buy more cheap water, increase the } \\
\text { harvests). In addition, environmental prob- } \\
\text { lems are being addressed - discharge to natu- } \\
\text { ral sources of water is reduced }\end{array}$ & $\begin{array}{l}\text { No provisions or guidelines have been } \\
\text { adopted }\end{array}$ \\
\hline
\end{tabular}




\begin{tabular}{|c|c|c|}
\hline Country & $\begin{array}{l}\text { Modern state of consumption of water, } \\
\text { including the water reuse }\end{array}$ & $\begin{array}{l}\text { Rules of application and stimulation of } \\
\text { financing of the water reuse }\end{array}$ \\
\hline$\overline{\mathrm{UK}}$ & $\begin{array}{l}\text { Effluents are used for maintenance of river } \\
\text { streams and ecosystems. This practice is es- } \\
\text { pecially developed on a south and east of } \\
\text { country on the large rivers. Effluents use also } \\
\text { for irrigation, including fields for golf, parks, } \\
\text { roads, washing of machines, in the systems of } \\
\text { cooling, fishing. Presently on experimental } \\
\text { basis projects TWWU will be realized in } \\
\text { laundries, washing off of rest rooms, etc., } \\
\text { there is one third of RU of domestic effluents } \\
\text { (sometimes the rain-water collected from the } \\
\text { roofs of houses interfuses with effluents) on } \\
\text { tha }\end{array}$ & $\begin{array}{l}\text { Realization of projects is complicated by } \\
\text { absence of clear reference-points in regard } \\
\text { to the use of effluents and level of their } \\
\text { cleaning. Leading principles on setting of } \\
\text { sewage treatment plants for cleaning of } \\
\text { flows with the purpose of their subsequent } \\
\text { use, reorganization of the water systems, to } \\
\text { their technical service, modernisations of } \\
\text { the pipeline system were published as early } \\
\text { as } 1999 \text { within the framework of Consulta- } \\
\text { tive System Adjusting Water Resources } \\
\text { (WRAS - Water Regulations Advisory } \\
\text { Scheme). In } 2005 \text { there is a research group } \\
\text { UKWIR, together with AWWA and Fund } \\
\text { repeated used }\end{array}$ \\
\hline
\end{tabular}

Source: authors based on (Alcalde-Sanz, Gawlik, 2014; Yerznkyan, Fontana, 2019b).

As we can see from the table, EU countries, from the point of view of presence of formal institutions and regulation practices on the treated wastewater reuse, can be divided into four groups, mamely countires:

- with the leading principles (Cyprus, Germany, Greece, France, Italy, Portugal, Spain, UK);

- where these principles are used fragmentary (Belgium, Hungary, Latvia, Netherlands);

- where these principles are in the stage of development or consideration (Bulgaria, Malta, Poland);

- where the leading principles are absent (Austria, Denmark, Ireland, Lithuania, Luxemburg, Romania, Slovakia, Slovenia, Finland, Czech Republic, Sweden, Estonia) (Yerznkyan, Fontana, 2019b, p. 21).

In countries (and not only European), where formal institutions (regulative directives) are absent or present partly, efficiency of the water reuse is arrived at due to the presence of informal practices, e.g. such as processes of collection and processing of data in cities. A good example is the platform of Boston City Score - online-instrument that accumulates data and municipal information reflecting efficiency of Boston as a city and its management system. Corresponding reports for the past day, week, month and quarter, so that everybody could to become familiar with actual information on management efficiency, are published on the city's web-site. Similar platforms are realized also in Los Angeles, New York and Houston. Their success demonstrates growing tendency to introduction of «management methods on basis of data», implying maximal use of data to increase the municipal economy's management efficiency and inform the habitants of results of realization of one or another decisions (Yerznkyan, Fontana, 2019a, p. 861). 


\section{CONCLUDING REMARKS}

Treated waste-water reuse in particular and a circular economy for water in general is tracted as one of the most fruitful instruments for providing population, organizations, businesses, state bodies, etc. with water resources. It should be added, that it is also one of the key factors for providng the sustainable development of a socio-economic system, in particular urban economy. Their use supposes support on innovations, digital technologies and effective management on the basis of possibilities, given by a circular economy. The last term serves for denotation a special type of economy being based on the use of renewable resources and contrasted in this sense to the traditional, linear economy, based on creation, use, and order by them.

Of particular importance for the implementation of TWWRU are institutions, both formal and informal. Among formal institutions, we note the directives, acts, and regulations adopted in many countries that can provide, after D. North (1990), the «game» with relevant «rules». Their success is largely determined by the support of formal institutions by informal ones. In general, as comparative institutional analysis has shown, TWWRU is a process both important and at the same time incomplete. However, no alternative is expected to ensure effective regulation of this process.

Summarizing, we emphasize that in addition to adopting effective «rules of the game» to achieve positive results in the rational and efficient use of water resources, the uninterrupted supply of clean water to the population, it is necessary to provide for a set of interrelated measures carried out jointly by state authorities, local self-government, private business, financial sector, and scientific organizations.

\section{REFERENCES}

1. Alcalde-Sanz L., Gawlik B. M. Water Reuse in Europe. Relevant guidelines need for and barriers to innovation. Third Main Title Line Third Line. A synoptic overview. European Commission. Joint Research Centre. Institute for Environment and Sustainability. Luxembourg: Publications Office of the European Union, 2014. (C) European Union 2014. DOI: 10.2788/29234.

2. Fontana, K.A., Fontana, C. (2016). Wastewater Use: A New Opportunity for the Green Economy. General Overview, Actual Problems of Humanitarian and Natural Sciences, 3, March, Part II: .811 (in Russ.).

3. North, D.C. (1990). Institutions, Institutional Change and Economic Performance. Cambridge: Cambridge University Press.

4. Strategy of ecological safety of Russian Federation on a period till 2025.

5. Yerznkyan, B.H., Fontana, K.A. (2018). Institutional Aspects of the Circular Economy's Development in the Sphere of Water Supply. Herald of CEMI RAS, 1 [Electronic resource]. Access for registered users. URL: http://cemi.jes.su/s111111110000079-9-1 (circulation date: 21.11.2018) (in Russ.).

6. Yerznkyan, B.H., Fontana, K.A. (2019a). Efficiency of Urban Water Resource Management and Its Evaluation. Economic Analysis: Theory and Practice, 18, 5: 855-876 (in Russ.).

7. Yerznkyan, B.H., Fontana, K.A. (2019b). Water Reuse and Its Regulation in Russia and Abroad, Materials of the International Conference «Scientific research of the SCO countries: synergy and integration» - Reports in English (July 12, 2019. Beijing, PRC). P.16-23. DOI; 10.34660/INF.2019.12.33342.

8. 2030 WRG [online link]. Available from: https://www.2030wrg.org/ (accessed on 15.03.2018). 


\section{Ерзнкян Б.А., Фонтана К.А. ИНСТИТУЦИОНАЛЬНЫЙ АНАЛИЗ МЕЖДУНАРОДНЫХ ПРАКТИК ПОВТОРНОГО ИСПОЛЬЗОВАНИЯ ВОДЫ}

Институциональный анализ предполагает учет воздействия институтов, как формальных, так и неформальных, на происходящие в экономической системе процессы - в нашем случае повторное использование очищенных сточных вод в городском хозяйстве. Среди интересующих нас формальных институтов особое место занимают законодательные акты и правила регулирования водохозяйственного комплекса, призванные обеспечить эффективное обеспечение водой как организаций и предприятий муниципального уровня, так и населения. В статье дается сравнительный анализ релевантных институтов регулирования в сфере водообеспечения в странах мира, в том числе и современной Европы. Релевантность определяется способностью институтов обеспечить устойчивое развитие водных ресурсов и предотвращения или смягчения водного кризиса. Дополнительно показано, что европейская практика повторного использования очищенных сточных вод является важным элементом для решения экологических проблем, компенсируя негативное влияние глобального изменения климата на городские экосистемы. Обсуждаются также некоторые особенности регулирования повторного использования воды как одного из возможных альтернативных источников воды в регионах, где они ограничены.

Ключевые слова: формальные и неформальные институты, повторное использование воды, устойчивое развитие, городское хозяйство, международные практики использования и регулирования водных ресурсов.

JEL классификащия: L31, O52, Q25, R58. 